\title{
The Great Oxidation Event Recorded in Paleoproterozoic Rocks from Fennoscandia
}

\author{
by Victor A. Melezhik, Aivo Lepland, Alexander E. Romashkin, Dmitry V. Rychanchik, \\ Melanie Mesli, Tor Erik Finne, Ronald Conze and the FAR-DEEP Scientists
}

doi:10.2204/iodp.sd.9.04.2010

With support of the International Continental Scientific Drilling Program (ICDP) and other funding organizations, the Fennoscandia Arctic Russia - Drilling Early Earth Project (FAR-DEEP) operations have been successfully completed during 2007. A total of 3650 meters of core have been recovered from fifteen holes drilled through sedimentary and volcanic formations in Fennoscandia (Fig. 1), recording several global environmental changes spanning the time interval 2500-2000 Ma, including the Great Oxidation Event (GOE) (Holland, 2002). The core was meanwhile curated and archived in Trondheim, Norway, and it has been sampled by an international team of scientists.

\section{Introduction}

The emergence of an aerobic Earth System and a series of interrelated global events (Archean-Paleoproterozoic Transition, APT) during the Late Archean and Early Paleoproterozoic (2500-2000 Ma) led to the irreversible alteration of Earth's surface (Fig. 2). This environmental change poses a fundamental challenge in the geosciences (Melezhik et al., 2005a). The FAR-DEEP Expedition specifically targeted geological formations 2500-2000 Ma old in three different areas (Fig. 1) that recorded most of the events associated with the GOE. The project has three major goals:

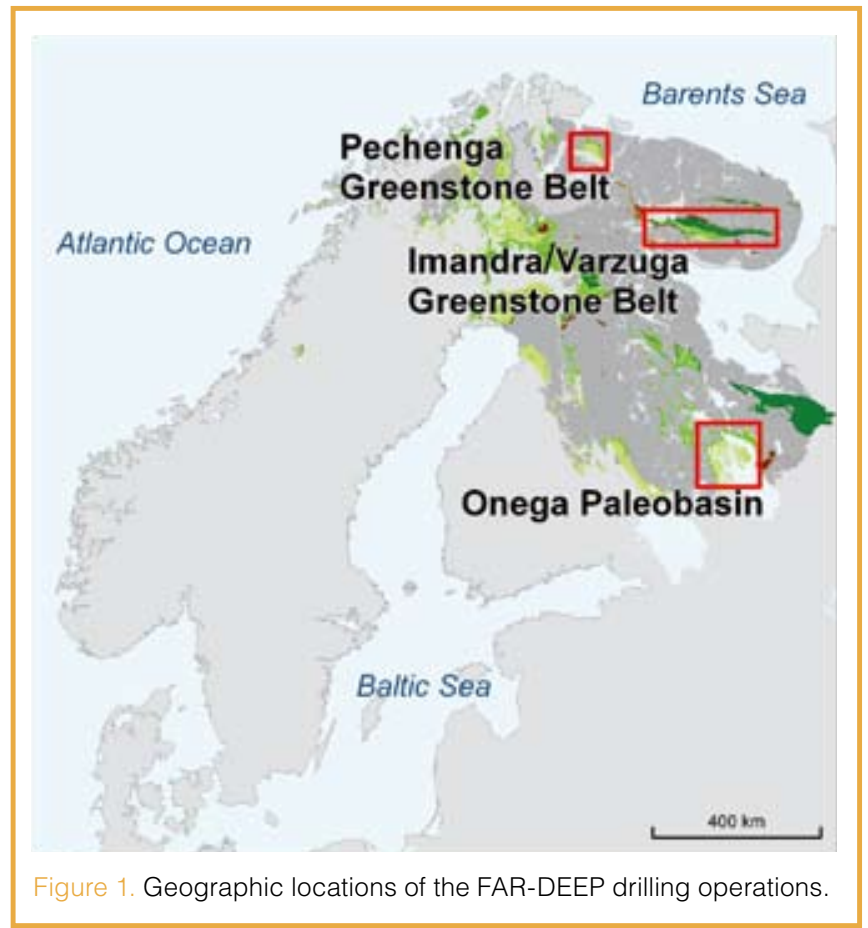

- Establish a well-characterized, well-dated, and well-curated succession of rocks for the period of 2500-2000 Ma

- Document the changes in the biosphere and the geosphere associated with the rise in atmospheric oxygen

- Develop a model to explain the genesis and timing of the establishment of the aerobic Earth System.

The samples obtained by the FAR-DEEP provide a representative geological record of the most important global events occurring through the APT (Fig. 2).

\section{Drilling Operations}

The drilling operations were carried out from May to October 2007 on the Russian part of the Fennoscandian Shield. The fifteen holes drilled range in depth from $92 \mathrm{~m}$ to $503 \mathrm{~m}$, totaling $3650 \mathrm{~m}$ of recovered core. To minimize the risk of core contamination for forthcoming biomarker studies, the drilling was performed with clear water and with non-oil-based lubricants. In most cases, the core recovery was close to $100 \%$. Most of the cores were successfully re-oriented, and they are suitable for paleomagnetic studies. The large distances and remoteness of the drilling sites with limited infrastructure required a considerable logistical effort. In addition the coring offered a unique opportunity for students from the FAR-DEEP partner institutions to examine field sites and participate in the recovery of the best available

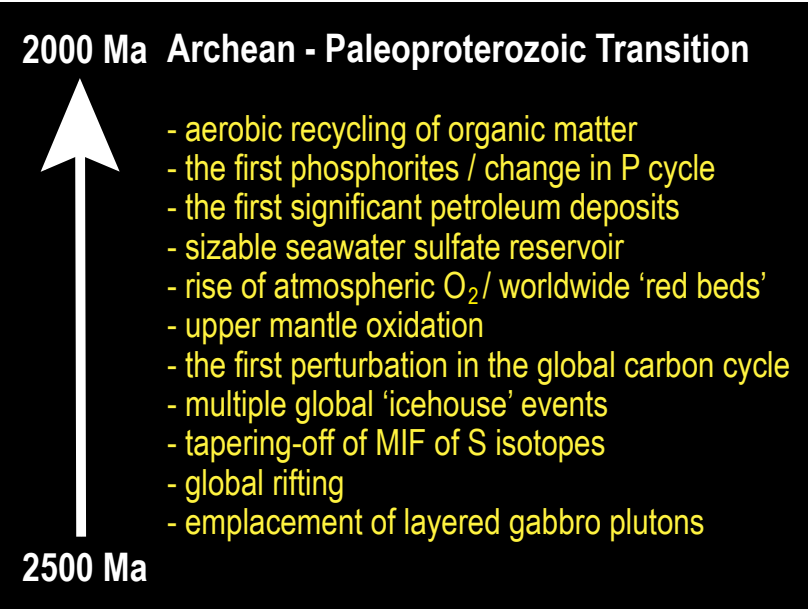

Global environmental events associated with the GOE, and targeted by FAR-DEEP (Holland, 2002). 
succession of volcanic-sedimentary rocks recording the time of emergence of an aerobic world.

\section{Core Archive and Drilling Information System (DIS)}

All cores were transported to the Geological Survey of Norway (NGU) in Trondheim for curation and archiving. All technical and geological data gathered during the drilling operations and through the archiving process have been catalogued using the Drilling Information System (DIS, see Web Links) developed by ICDP. During the project, the functions of this software have been continuously updated to meet the specific FAR-DEEP needs. The archive process began in March and was completed by December 2008 .

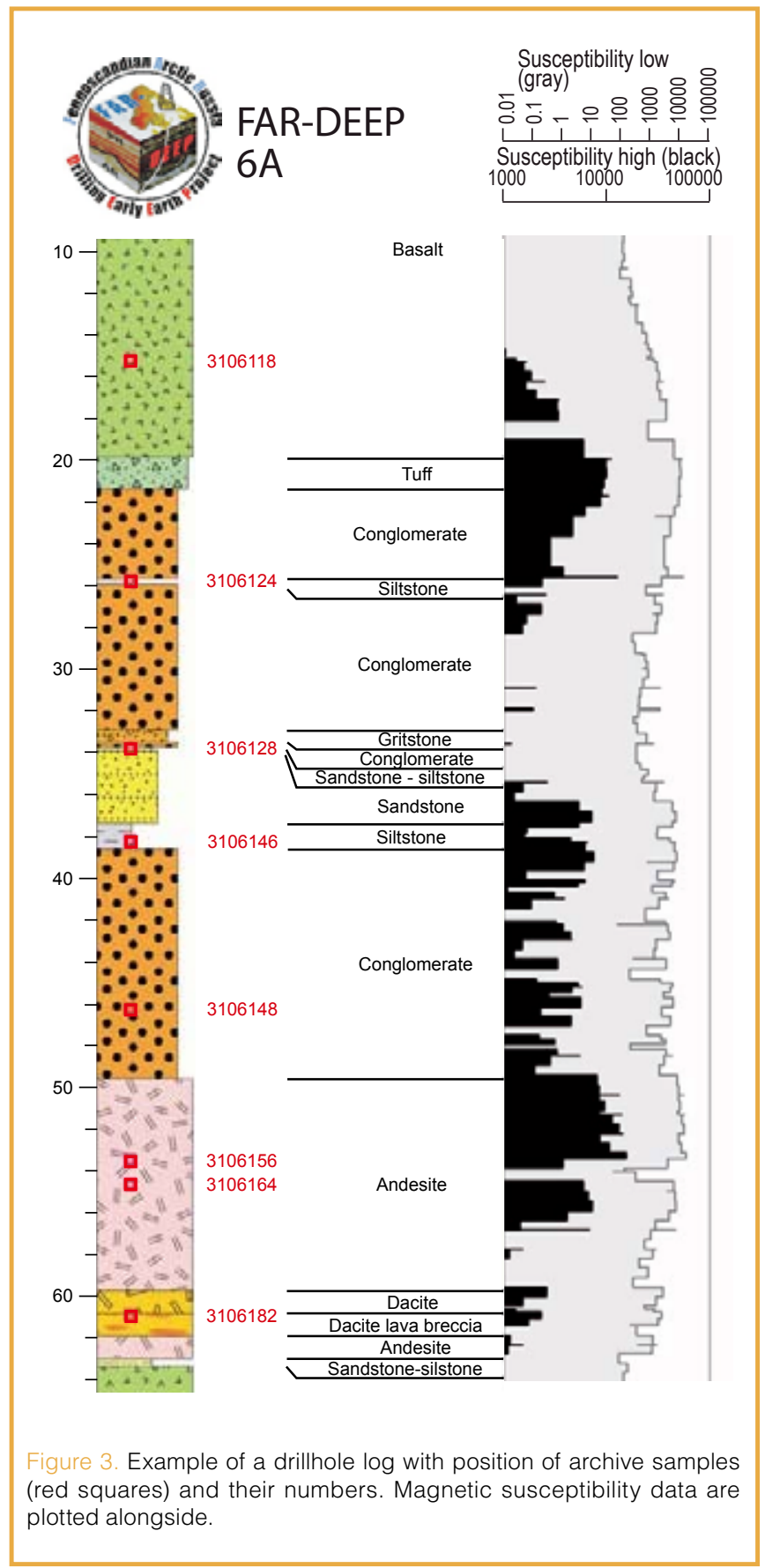

At the NGU's core repository the archive process included (1) high-resolution photography of core in boxes, in dry and wet conditions, (2) magnetic susceptibility measurements of full core at $\sim 20$-cm intervals, (3) core splitting by sawing, (4) image scanning and photography of split core, (5) detailed lithological description, (6) and routine sampling with $\sim 7-\mathrm{m}$ spacing for general geochemical and petrographic characterizations of the rocks. The archive sample set consists of 554 specimens that have been analyzed for whole-rock major and trace elements, carbonate composition, abundance of $\mathrm{C}$ and $\mathrm{S}$, and thin sections have been made from them at the NGU laboratory. Selected specimens from the archive set have been analyzed for $\mathrm{S}$ isotopes of sulfides, $\mathrm{C}$ - and $\mathrm{N}$-isotopes of the organic matter, and $\mathrm{C}$-, $\mathrm{O}$-, and $\mathrm{Sr}$-isotopes of carbonates by the FAR-DEEP international team of researchers. All documentation obtained during the archiving process and general geochemical profiles of cores (Fig. 3) were made available for the FAR-DEEP partners on the Internet prior to core sampling in Trondheim from March to April 2009.

\section{"Coring" through Major Paleoproterozoic Events and Paleoproterozoic Reference Sections}

The FAR-DEEP cores of sedimentary and volcanic formations in the stratotype areas of the Pechenga and Imandra/Varzuga Greenstone Belts and the Onega Basin (Fig. 1) record the global events of the APT (Figs. 4 and 5).

Change in fractionation of sulfur isotopes. Several lines of evidence imply Earth's earliest atmosphere shifted from being anoxic to oxic between $2500 \mathrm{Ma}$ and $2000 \mathrm{Ma}$ (GOE, Fig. 2). The processes driving this shift, as well as their timing and duration, remain enigmatic. Appearance of 'red beds' and sulfates in the stratigraphic record is among the most compelling evidence reflecting the change to oxic conditions. Additional support for the oxygenation has been gained from recent work on S-isotopes that have shown the presence of mass-independently fractionated (MIF) S-isotopes in rocks older than 2360 Ma and disappearance of such a signature thereafter (Bekker et al., 2004; Hannah et al., 2004; Guo et al., 2009). The disappearance of MIF S-isotopes has been typically attributed to the oxygenation of the atmosphere and related change in photochemical reactions, but other processes have also been proposed (Watanabe et al., 2009). FAR-DEEP's drillhole $1 \mathrm{~A}$ intersected a sequence of marine shales (Fig. 6A) and sandstones deposited prior to $2442 \mathrm{Ma}$ (Fig. 4). These 2442-Ma rocks show a transition from MIF to mass-dependently fractionated sulfur isotopes (Reuschel et al., 2008); thus, they offer new constraints on the S-isotope cycle at the dawn of the GOE. Moreover, isotope geochemistry of marine carbonate rocks interbedded with shales may represent a robust proxy for the global carbon cycle prior to the Huronian-age glaciation (Young et al., 2001). 
Huronian-age global glaciation. The rapid onset of global glaciation(s) from otherwise climatically invariant conditions at around $2320 \mathrm{Ma}$ (age constraint from South Africa, Hannah et al., 2004) is another significant environmental event during the APT. The triggering mechanisms remain poorly understood (Evans, 2003) and several models have been advanced to explain them (Melezhik, 2006; Claire et al., 2006). In the Imandra/Varzuga Greenstone Belt, drillhole $3 \mathrm{~A}$ intersected Huronian-age diamictites (Fig. 6B). These are overlain by spinifex-textured komatiites (Fig. 6C) and underlain by Sr-rich limestones, all resting on felsic volcanic rocks. This setting offers unique opportunities for reconstructing paleolatitudinal positions, a geochemical record of seawater Sr- and $\mathrm{C}$-isotopic composition and geochrono$\log$.

Unprecedented perturbation of the global carbon cycle. The largest positive excursion of $\delta^{13} \mathrm{C}$ known in Earth's history as recorded in sedimentary carbonatestermed the Lomagundi-Jatuli Event-is one of a series of prominent Paleoproterozoic environmental events whose interrelationships remain intriguing and only partially resolved (Melezhik et al., 2007). At present, no consensus exists on the causative mechanism(s) responsible for the Lomagundi-Jatuli Event (Bekker et al., 2001, 2003a; Hayes and Waldbauer, 2006). The possible role of local factors in amplification of a global signal remains unresolved (Melezhik et al., 1999; Bekker et al., 2003a, 2003b; Aharon, 2005). Drillholes 4A, 5A, 10A, 10B, and 11A intersected ${ }^{13} \mathrm{C}$-rich carbonates of the Lomagundi-Jatuli Event (Fig. 6D) in three different depositional and paleotectonic settings. Drillholes $8 \mathrm{~A}$ and $8 \mathrm{~B}$ cored carbonates (Fig. 6E) that post-date the Lomagundi-Jatuli Event. The study of all these cores will help to understand onset, duration, and causes of this unique perturbation of the global carbon cycle.

Oxidized ocean - abundant Ca-sulfates. Progressive oxygenation of Earth's surface environments resulted in increased sulfide oxidation during continental weathering and a concomitant increase in the concentration of marine sulfate (Guo et al., 2009). However, to date, available esti-mates of marine sul-

\section{Pechenga \& Imandra/Varzuga Greenstone Belts}

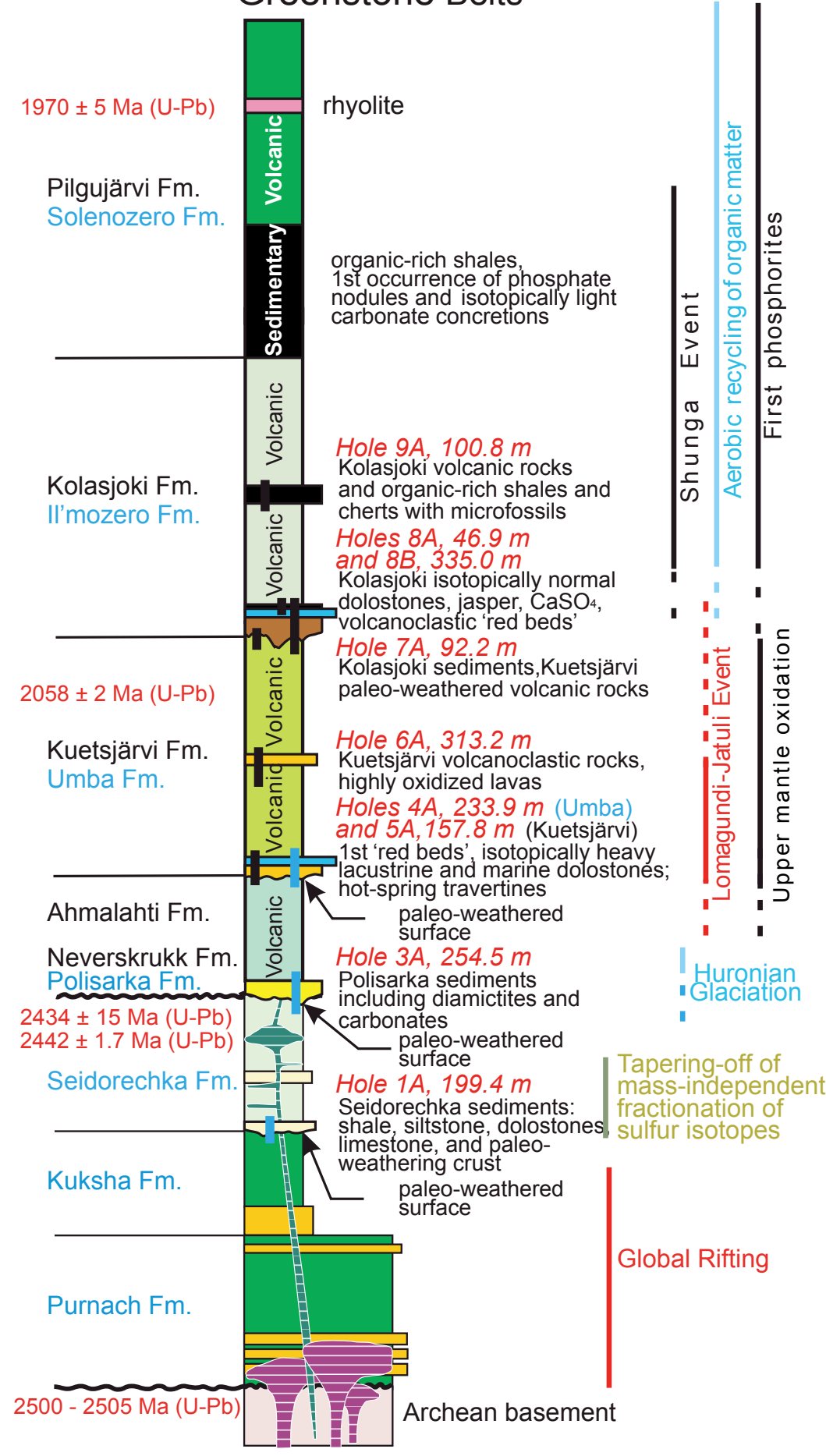

Composite ( 10,000-m-thick) and simplified Paleoproterozoic section for the Pechenga and Imandra/Varzuga Greenstone Belts linked to major paleoenvironmental events. Radiometric dates from bottom to top are from Amelin et al. (1995), Melezhik et al. (2007), and Hanski (1992). The Pechenga Belt stratigraphy is shown in black-face letters, and the drilled holes by vertical black lines; features for the Imandra/Varzuga Belt are in blue. The number of the drillhole and its depth are shown in red-face letters; this is followed by text briefly describing rock lithologies intersected by the hole. fate reservoir size remain controversial (Kah et al., 2004; Melezhik et al., 2005b),. Several FAR-DEEP drillholes (5A, $8 \mathrm{~A}, 8 \mathrm{~B}, 10 \mathrm{~A}, 10 \mathrm{~B}, 11 \mathrm{~A})$ successfully targeted sedimentary 
formations that contain seawater sulfates. Pseudomorphs after gypsum and anhydrite, with relicts of primary minerals, have been documented in great abundance (Fig. 6F, $6 \mathrm{G})$. Detailed mineralogical and isotopic studies to decipher their environmental significance are in progress and will help constrain the oxygenation history.

Ferric iron-rich volcanic rocks: upper mantle oxidizing event vs. secondary overprint by oxidized groundwaters. Was the rise of atmospheric oxygen levels related to increased dioxygen due to evolution of oxygen-producing organisms, or was it controlled by a decrease in oxygen sinks (Kump, 2008)? One hypothesis is that a predominant sink for oxygen in the Archean era was abruptly and permanently diminished during the APT (Kump and Barley, 2007), but the overall cause of the GOE remains unresolved. Approximately 2060-Ma-old volcanic rocks (Fig. 6H, 6I) in the Pechenga Greenstone Belt have high $\mathrm{Fe}^{3+} / \mathrm{Fe}_{\text {total }}$ ratios (average=0.37) which are in sharp contrast to the majority of underlying and overlying volcanic units. The FAR-DEEP drillholes $4 \mathrm{~A}$ and

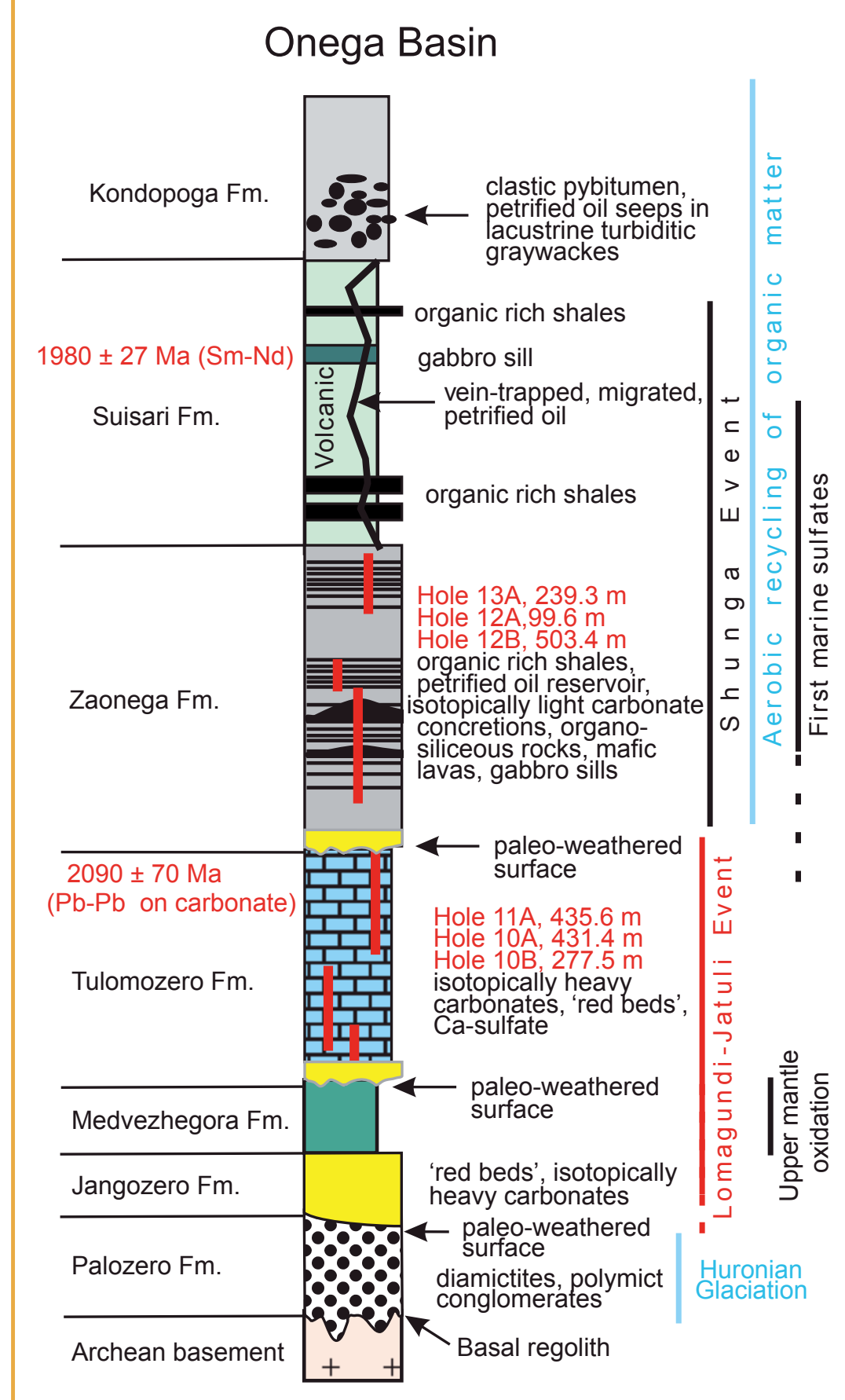

Composite ( 5000-m-thick) and simplified Paleoproterozoic section for the Onega Basin linked to major paleoenvironmental events. Radiometric dates from bottom to top are from Ovchinnikova et al. (2007) and Pukhtel et al. (1992). Vertical red lines show the position of the drillholes. The number of the drillhole and its depth are shown in red-face letters; this is followed by text briefly describing rock lithologies intersected by the hole.
$6 \mathrm{~A}$ recovered more than 300 meters of such highly oxidized lavas (Fig. 6I). This anomaly may represent evidence either for relatively oxidized mantle material (e.g., recycled banded iron formations) or a large-scale alteration of Earth's surface by oxidized meteoric and/or groundwaters.

Subaerial and subaqueous hydrothermal systems. Two types of compositionally different hydrothermal products have been documented in the FAR-DEEP drillcores. The first type is represented by iron oxide-silica-dominated rocks (jasper). This appears in a large variety of occurrences in the FAR-DEEP cores, including numerous amygdales (Fig. 6I), veinlets and veins in volcanic rocks (Fig. 6J), siltstoneand dolostone-hosted layers, beds, and feeder-veinlets in dolostones and siliciclastic sediments (Fig. 6K), and redeposited clasts in fluvial, deltaic and marine sediments. The occurrences of jasper thus represent a complex history of fluid migration and redox alteration in a suite of processes linked to the GOE.

The second type of hydrothermal products is travertine (Fig. 6L), occurring in great abundance as thin crusts and feeder-veinlets in ${ }^{13} \mathrm{C}$-rich lacustrine dolostones (Fig. 4, Kuetsjärvi Fm). These oldest ever documented travertines may signify a radical change in Earth surface environment to one allowing the precipitation of hydrothermal carbonates in subaerial conditions. Drillcores from holes 5A, 6A, 7A, 8A, and 8B provide excellent material for studying the complex 'iron story' around the GOE, as well as the earliest known travertine-precipitating hydrothermal systems.

\section{Revolution in biological cycling of phosphorous and organic matter.} Post-Lomagundi-Jatuli deposits (2000 Ma) record the first known appearance (if siderite in banded iron formations is excluded) of 

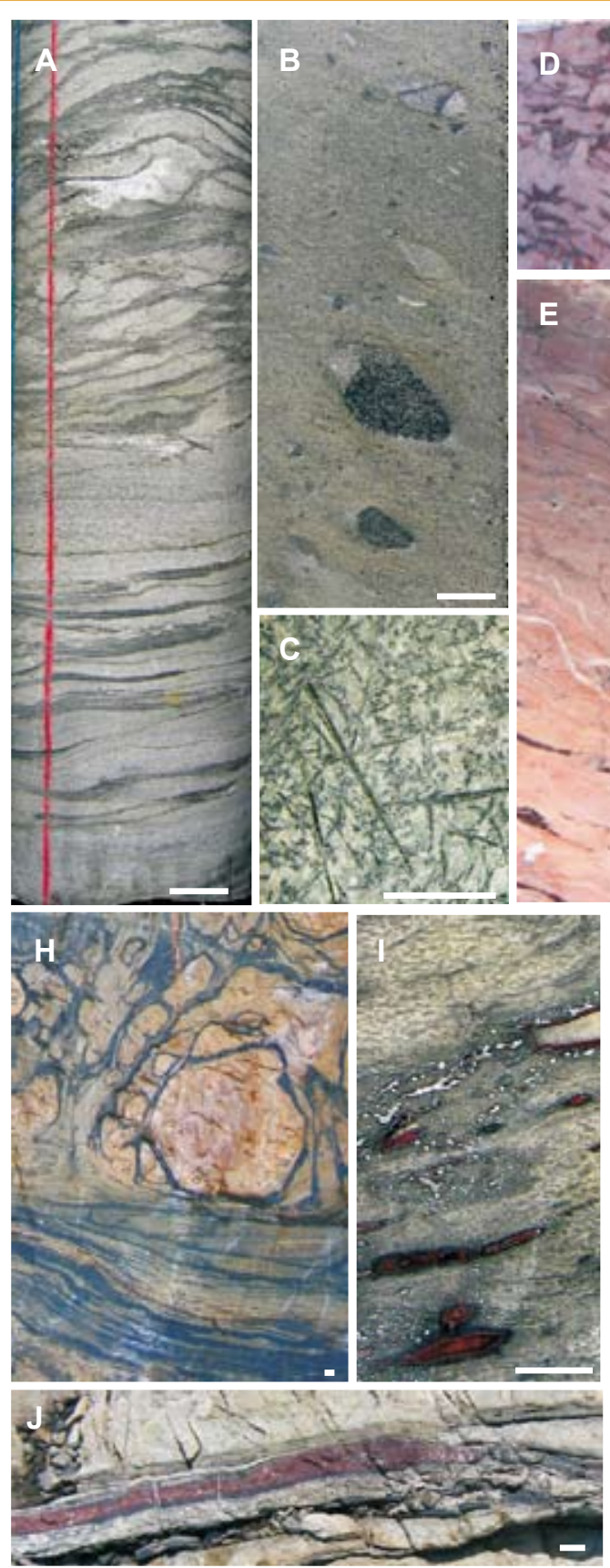
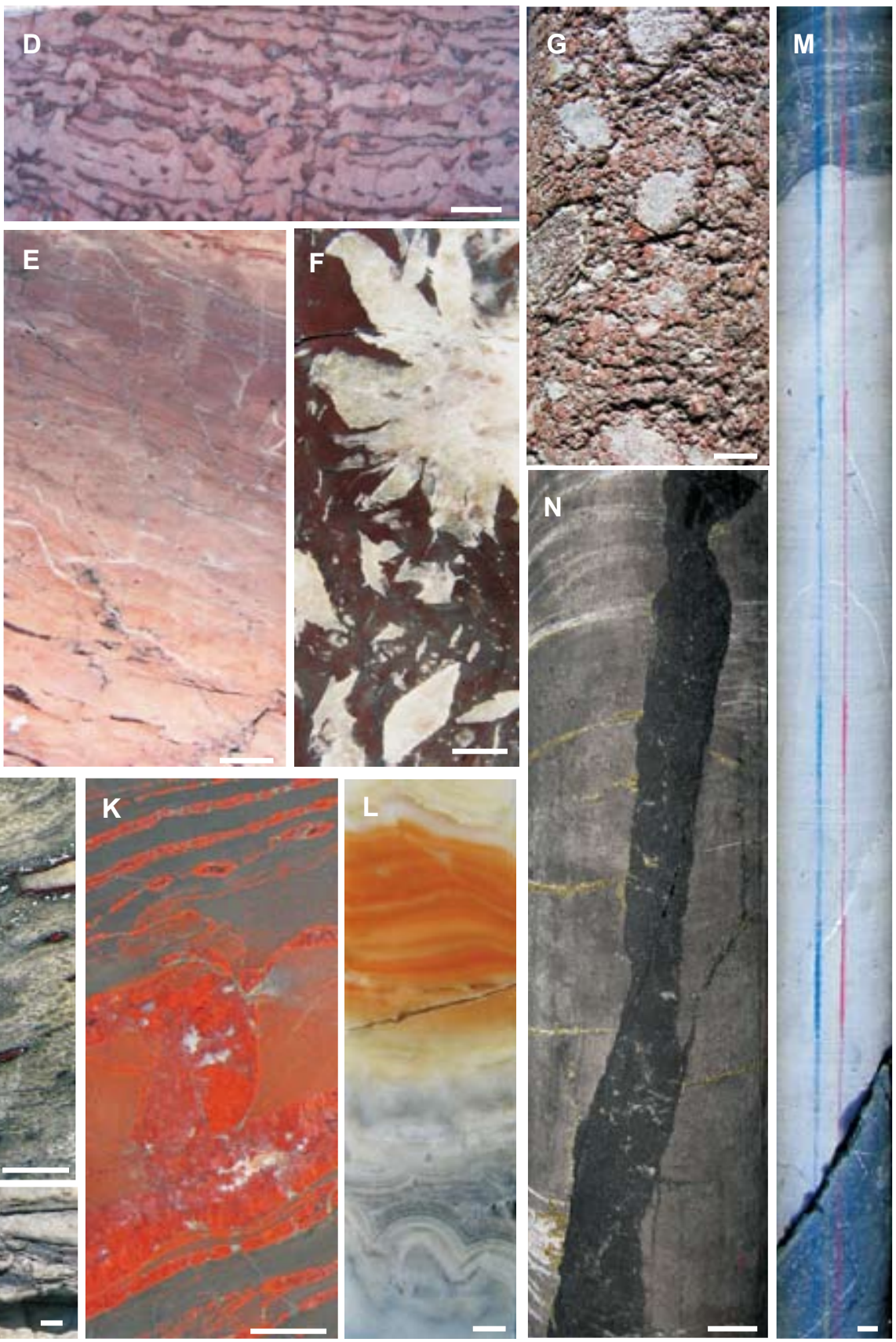

Major Paleoproterozoic paleoenvironmental events documented in the FAR-DEEP cores and adjacent outcrops. [A] Sandstone-shale from drillhole $1 \mathrm{~A}$ with tidal bedding formed at the start of the GOE. [B] Diamictite accumulated during the Huronian-global glaciation; drillhole 3A. [C] Spinifex-structured komatiites overlying the diamictites; drillhole 3A. [D] Jatuli-age, red, stromatolitic, ${ }^{13} \mathrm{C}$-rich, dolostone recording the unprecedented perturbation of the global carbon cycle during the Lomagundi-Jatuli Event; red color is indicative of oxic environment associated with GOE; drillhole 10A. [E] Post-Lomagundi-Jatuli, pink, isotopically "normal", dolostone recording the recovery from the perturbation in the global carbon cycle; drillhole 8B. [F] Dolomite-quartz pseudomorphs after gypsum rosette and crystals emplaced in red clay; abundant Ca-sulfates suggest a significant ocean sulfate reservoir; drillhole 10B. [G] Dissolution of anhydrite and halite resulted in porous appearance of matrix-supported conglomerate; drillhole 11A. [H] 2060-Ma weathering surface imprinted in hematite-cemented (black) felsic lava-breccia in vicinity of drillhole 7A; this is indicative of oxic meteoric and ground waters during the GOE. [I] Jasper-filled amygdales (dark red) in oxidized felsic lava from drillhole 6A; this may record an upper mantle oxidizing event. [J] Jasper vein in dacitic lava near drillhole 7A; such veins are truncated by overlying sediments and are the product of subaerial, syn-volcanic hydrothermal activity. [K] Greywacke-hosted jasper layers and beds precipitated from sub-aqueous hydrothermal system; drillhole 8B. [L] The earliest known travertines on Earth from drillhole 5A. [M] ${ }^{13} \mathrm{C}$-depleted carbonate concretion incorporating carbon derived from oxic recycling of the organic matter; drillhole 12B. Bar scales in all photos are $1 \mathrm{~cm}$. [N] Pyrobitumen vein representing a 2000-Ma oil migration pathway; drillhole 12A. These units contain both mass-independent and massdependent fractionation of sulfur isotopes.

diagenetic carbonate concretions significantly depleted in ${ }^{13} \mathrm{C}$ (Fallick et al., 2008). They are varied in size and composition and abundant in sedimentary successions $<2000 \mathrm{Ma}$ where they are associated with other diagenetic products such as phosphorites, all of which are seemingly absent in older rocks. Thus, these suggest a major change in the diagenetic mineralization of organic matter, perhaps reflecting increased rates in dissimilatory sulfate reduction (Canfield and Raiswell, 1999). This in turn suggests an elevated concentration of interstitial phosphate. Drillholes 9A, 12A, 12B, 
and $13 \mathrm{~A}$ recovered hundreds of meters of cores containing abundant carbonate nodules (Fig. 6M) and carbonate-associated phosphorites, which allow us to address the causes of the emergence of 'modern-style' recycling of organic matter, are and the factors that control the formation of the oldest known phosphorites.

Supergiant petroleum deposits. The most remarkable accumulation of organic-matter-rich sediments and generation of petroleum in the Precambrian took place at around $2000 \mathrm{Ma}$ ago in the aftermath of the Lomagundi-Jatuli Event (Melezhik et al., 2009). This is known as the Shunga Event. The causes (e.g., high productivity or anomalous preservation) of such unprecedented global accumulation of organic-matter and pervasive oil generation remain unknown. In the type area at Shunga, three FAR-DEEP drillholes (12A, 12B, 13A) intersected several hundred meters of organic matter-rich source rocks, a uniquely preserved oil migration pathway (Fig. 6N), a petrified supergiant oilfield, and several bodies of enigmatic organo-siliceous rocks containing up to $40 \mathrm{wt} \%$ organic carbon. More than 100 archive samples have already been analyzed for major and trace elements as well as for S- and $\mathrm{C}$-isotopes of sulfides, organic matter and associated carbonates, and they indicate a complex geochemical evolutionary pattern. These data, together with the results of forthcoming studies on biomarkers and structural, isotopic, and trace element characteristics of organic matter, will enable several fundamental problems associated with the Shunga Event to be addressed.

\section{International Sampling and Acknowledgements}

The drilling operations were carried out by a Finnish operator, whereas all logistical support was provided by the Russian State Company "Mineral" from St. Petersburg, Russia. Selected specimens from the archive set have been analyzed by partners at the Westfälische WilhelmsUniversität, Münster, Germany (H. Strauss), the Scottish Universities Environmental Research Center, Glasgow, Scotland (A.E. Fallick), the Pennsylvania State University, U.S.A. (L.R. Kump), and the Institute of Precambrian Geology and Geochronology, St. Petersburg, Russia (I.M. Gorokhov). The NGU, Center of Excellence in Geobiology at the University of Bergen in Norway, and the Institute of Geology at the Karelian Research Center in Petrozavodsk, Russia provided resources for the archiving work. In March-April 2009, the NGU provided its facilities and logistical support for an international sampling campaign. Samples have been collected either directly by scientists who have examined the core in Trondheim or by the NGU's staff upon sample requests submitted by FAR-DEEP partners. More than 5500 samples have been collected from cores, and they are being prepared for various analyses and experiments. Scientists from thirteen countries have applied for research grants from various funding agencies to com- plete studies of the FAR-DEEP cores. Currently, five PhD students from Finland, Germany, and Norway are involved in the FAR-DEEP research program. Four postdoctoral projects in Finland, Great Britain, and Norway have been financed by national funding agencies. A large group of scientists from the U.S.A. has received support from the U.S. National Science Foundation and NASA. Several research groups from Australia, Belgium, Czech Republic, Estonia, and Russia have also been successful in obtaining research grants.

\section{References}

Aharon, P., 2005. Redox stratification and anoxia of the early Precambrian oceans: Implications for carbon isotope excursions and oxidation events. Precam. Res., 137:207-222.

Amelin, Yu.V., Heaman, L.M., and Semenov, V.S., 1995. U-Pb geochronology of layered mafic intrusions in the eastern Baltic Shield: Implications for the timing and duration of Palaeoproterozoic continental rifting. Precam. Res., 75:31-46, doi:10.1016/0301-9268(95)00015-W.

Bekker, A., Holland, H.D., Wang, P.L., Rumble III, D., Stein, H.J., Hannah, J.L., Coetzee, L.L., and Beukes, N.J., 2004. Dating the rise of atmospheric oxygen. Nature, 427:117-120, doi:10.1038/nature02260.

Bekker, A., Karhu, J.A., Eriksson, K.A. and Kaufman, A.J., 2003a. Chemostratigraphy of Paleoproterozoic carbonate successions of the Wyoming Craton: Tectonic forcing of biogeochemical change? Precam. Res., 120:279-325, doi:10.1016/ S0301-9268(02)00164-X.

Bekker, A., Kaufman, A.J., Karhu, J.A., Beukes, N.J., Swart, Q.D., Coetzee, L.L., and Eriksson, K.A., 2001. Chemostratigraphy of the Paleoproterozoic Duitschland Formation, South Africa: Implications for coupled climate change and carbon cycling. Am. J. Sci., 301:261-285, doi:10.2475/ajs.301.3.261.

Bekker, A., Sial, A.N., Karhu, J.A., Ferreira, V.P., Noce, C.M., Kaufman, A.J., Romano, A.W., and Pimentel, M.M., 2003b. Chemostratigraphy of carbonates from the Minas Supergroup, Quadrilátero ferrífero (Iron Quadrangle), Brazil: a stratigraphic record of Early Proterozoic atmospheric, biogeochemical and climatic change. Am. J. Sci., 303:865-904, doi:10.2475/ajs.303.10.865.

Canfield, D.E., and Raiswell, R., 1999. The evolution of the sulfur cycle. Am. J. Sci., 299: 97-723, doi:10.2475/ajs.299.7-9.697.

Claire, M.W., Catling, D.C., and Zahnle, K.J., 2006. Biogeochemical modelling of the rise in atmospheric oxygen. Geobiology, 4:239-269, doi:10.1111/j.1472-4669.2006.00084.x.

Evans, D.A.D., 2003. A fundamental Precambrian-Phanerozoic shift in Earth's glacial style? Tectonophysics, 375:353-385, doi:10.1016/S0040-1951(03)00345-7.

Fallick, A.E., Melezhik, V.A., and Simonson, B., 2008. The ancient anoxic biosphere was not as we know it. In Dobretsov, N., Kolchanov, N., Rozanov, A., and Zavarzin, G. (Eds.) Biosphere Origin and Evolution. New York (Springer Science + Business Media), 169-188.

Guo, Q., Strauss, H., Kaufman, A.J., Schröder, S., Gutzmer, J., Wing, B., Baker, M.A., Bekker, A., Kim, S.-T., Jin, Q., and Farquhar, 
J., 2009. Reconstructing Earth's surface oxidation across the Archean-Proterozoic transition. Geology, 37:399-402, doi:10.1130/G25423A.1.

Hannah, J.L., Bekker, A., Stein, H.J., Markey, R.J., and Holland, H.D., 2004. Primitive Os and $2316 \mathrm{Ma}$ age for marine shale: Implications for Paleoproterozoic glacial events and the rise of atmospheric oxygen. Earth Planet. Sci. Lett., 225:43-52, doi:10.1016/j.epsl.2004.06.013.

Hanski, E.J., 1992. Petrology of the Pechenga ferropicrites and cogenetic, Ni-bearing gabbro-wehrlite intrusions, Kola Peninsula, Russia. Geol. Survey Finland Bull., 367, 191 pp.

Hayes, J.M., and Waldbauer, J.R., 2006. The carbon cycle and associated redox processes through time. Philos. Trans. R. Soc. Lond. B Biol. Sci., 361:931-950.

Holland, H.D., 2002. Volcanic gases, black smokers, and the great oxidation event. Geochim. Cosmochim. Acta, 66:3811-3826, doi:10.1016/S0016-7037(02)00950-X.

Kah, L.C., Lyons, T.W., and Frank, T.D., 2004. Low marine sulfate and protracted oxygenation of the Proterozoic biosphere. Nature, 431:834-838, doi:10.1038/nature02974.

Kump, L.R., 2008. The rise of atmospheric oxygen. Nature, 451:277-278, doi:10.1038/nature06587.

Kump, L.R., and Barley, M.E., 2007. Increased subaerial volcanism and the rise of atmospheric oxygen 2.5 billion years ago. Nature, 448:1033-1036, doi:10.1038/nature06058.

Melezhik, V.A., 2006. Multiple causes of Earth's earliest global glaciation. Terra Nova, 18:130-137, doi:10.1111/j.1365-3121. 2006.00672.x.

Melezhik, V.A., Fallick, A.E., Filippov, M.M., Lepland, A., Rychanchik, D.V., Deines, Y.E., Medvedev, P.V., Romashkin, A.E., and Strauss, H., 2009. Petroleum surface oil seeps from Palaeoproterozoic petrified giant oilfield. Terra Nova, 21:119-126, doi:10.1111/j.1365-3121.2009.00864.x.

Melezhik, V.A., Fallick, A.E., Hanski, E.J., Kump, L.R., Lepland, A., Prave, A.R., and Strauss, H., 2005a. Emergence of the aerobic biosphere during the Archean-Proterozoic transition: Challenges of future research. Geol. Soc. Am. Today, 15:4-11.

Melezhik, V.A., Fallick, A.E., Medvedev, P.V., and Makarikhin, V.V., 1999. Extreme ${ }^{13} \mathrm{C}_{\text {carb }}$ enrichment in ca. 2.0 Ga magnesitestromatolite-dolomite-'red beds' association in a global context: a case for the world-wide signal enhanced by a local environment. Earth Sci. Rev., 48:71-120, doi:10.1016/S00128252(99)00044-6.

Melezhik, V.A., Fallick, A.E., Rychanchik, D.V., and Kuznetsov, A.B., 2005b. Palaeoproterozoic evaporites in Fennoscandia: Implications for seawater sulfate, $\delta^{13} \mathrm{C}$ excursions and the rise of atmospheric oxygen. Terra Nova, 17:141-148, doi:10.1111/j.1365-3121.2005.00600.x.

Melezhik, V.A., Huhma, H., Condon, D.J., Fallick, A.E., and Whitehouse, M.J., 2007. Temporal constraints on the Paleoproterozoic Lomagundi-Jatuli carbon isotopic event. Geology, 35:655-658, doi:10.1130/G23764A.1.

Ovchinnikova, G.V., Kusnetzov, A.B., Melezhik, V.A., Gorokhov, I.M., Vasil'eva, I.M., and Gorokhovskii, B.M., 2007. Pb-Pb age of Jatulian carbonate rocks: the Tulomozero Formation of southeast Karelia. Strat. Geol. Correl., 15(4):359-372.
Pukhtel, I.S., Zhuravlev, D.Z., Ashikhmina, N.A., Kulikov, V.S., and Kulikova, V.V., 1992. Sm-Nd age of the Suisarian suite on the Baltic Shield. Trans. Russian Acad. Sci., 326:706-711. (in Russian).

Reuschel, M., Strauss, H., Fallick, A.E., and Melezhik, V., 2008. FAR-DEEP: Sulphur biogeochemistry in deep time. 33rd International Geological Congress, Oslo, 6-14 August 2008.

Watanabe, Y., Farquhar, J., and Ohmoto, H., 2009. Anomalous fractionations of sulfur isotopes during thermochemical reduction. Science, 324:370-373, doi:10.1126/science. 1169289.

Young, G.M., Long, D.G.F, Fedo, C.M., and Nesbitt, H.W., 2001. Paleoproterozoic Huronian basin: Product of a Wilson cycle punctuated by glaciations and a meteorite impact. Sed. Geol., 141/142:233-254, doi:10.1016/S0037-0738(01) 00076-8.

\section{Authors}

Victor A. Melezhik, Geological Survey of Norway, N-4791, Trondheim, Norway; Centre for Geobiology, University of Bergen, N-5020, Bergen, Norway, e-mail: victor.melezhik@ ngu.no.

Aivo Lepland, Melanie Mesli, Tor Erik Finne, Geological Survey of Norway, N-4791, Trondheim, Norway.

Alexander E. Romashkin and Dmitry V. Rychanchik, Institute of Geology of Karelian Research Centre, 185610, Petrozavodsk, Russia.

Ronald Conze, Operational Support Group ICDP, GFZ German Research Center for Geosciences (GeoForschungsZentrum Potsdam), D-14473 Potsdam, Germany.

\section{and the FAR-DEEP Scientists}

\section{Web Links}

http://far-deep.icdp-online.org (Internal Data FARDEEP) http://www.icdp-online.org/front_content.php?idart=1962 